\title{
Modelling and Energy Analysis of Solid Oxide Fuel Cell (SOFC) Operated by the PV System in the Residential Sector in Australia
}

\author{
Scarlett Allende \\ Los Zarzales 1533, Santiago 9270842. Chile, \\ ssallend@uc.cl
}

\begin{abstract}
This paper presents an energy evaluation of a hybrid system composed of a photovoltaic farm, hydrogen consumption and solid oxide fuel cell, which simulation involves the electric demand of a household in the Western territory of Australia. Specifically, the study evidences a significant solar potential that provides $4659 \mathrm{kWh} /$ year. However, there is an energy deficit in the period when the load energy is higher than the solar generation. As a result, the fuel cell integration solves the irregularities of solar availability, providing $4567 \mathrm{kWh} /$ year load demand and $477827 \mathrm{kWh} /$ year of energy delivered to the grid. Finally, the configuration of the system generates $50 \%$ more than the energy required, which allows enlarging the electric consumption and the possibility to append thermal energy.
\end{abstract}

Keywords - Hybrid system, Fuel cell, Photovoltaic, Hydrogen, Residential sector, Energy demand.

\section{INTRODUCTION}

The primary purpose of this study is to know the potential of the natural sources of Western Australia, determine the electricity and hydrogen demand, analyse the integration of the fuel cell into PV system and evaluate the hybrid system performance. Overall, Australia presents a significant development in the renewable energies due to natural resources available and the target of clean energy regulation existing in different states [1]. Particularly, WA has a relevant potential in renewable's energies, particularly in solar households with $27 \%$ of capacity (rooftop solar technology) [2].

The high solar radiation in Australia allows getting progress in the industry, especially in the desert areas (northwest and centre), resulting in total solar radiation of 58 million PJ. Also, due to the policies of clean energy, the government expects to generate $1000 \mathrm{MW}$ from solar power, promoting the capacity of electric and thermal technologies, though, the current production of solar energy denotes $0.1 \%$ of the total primary energy demand [3]
At the same time, Australia has expanded the type of renewable resources, such as the hydrogen industry that allows exploring new technologies, including fuel cell development. Specifically, the implementation of the fuel cell as an electric generator provides a reliable energy system due to the option of seasonal hydrogen storage and grid stability. Furthermore, it's an alternative to remote area power systems [4].

\section{METHODOLOGY}

\section{A. Estimating Energy Demand}

The annual electric demand was calculated considering the simulator plan of Australian energy consumption [5]. The study understands factors that influence electrical use, such as the location, number of people living in the house and the usage of facilities. Specifically, the simulation applied in this paper involved the electric consumption of two people, which includes the pool facilities and slab heating system. Equivalently, the daily and hourly use were calculated based on the periods of electric usage, considering the distribution of the energy plan simulation on the 8760 hours per year.

\section{Photovoltaic farm}

The solar research was in the coordinates -25.69 , 116.2, which corresponds to the Western territory of Australia. The first step of the study involved obtaining the monthly data of temperature and solar irradiation, extracted from the photovoltaic geographical information system [6]. These data correspond to the average hourly of air temperature $\left[{ }^{\circ} \mathrm{C}\right]$ and the global and diffuse radiation $\left[\mathrm{kWh} / \mathrm{m}^{2}\right]$ of each month. Considering these last two data was possible to estimate the slope radiation $\left[\mathrm{kWh} / \mathrm{m}^{2}\right]$. Fig. 1 explains the sequence of steps done on this methodology.

It is important to note that Fig. 1 is modified from a similar study [7], where the hourly global and diffuse solar irradiation $\left(\mathrm{kWh} / \mathrm{m}^{2}\right)$ were from the NASA 
database. However, this research considered the PVGIS Explorer data. The rest of the steps follows the same logic. The resulting diagram explains the sequence of the steps done on this methodology.

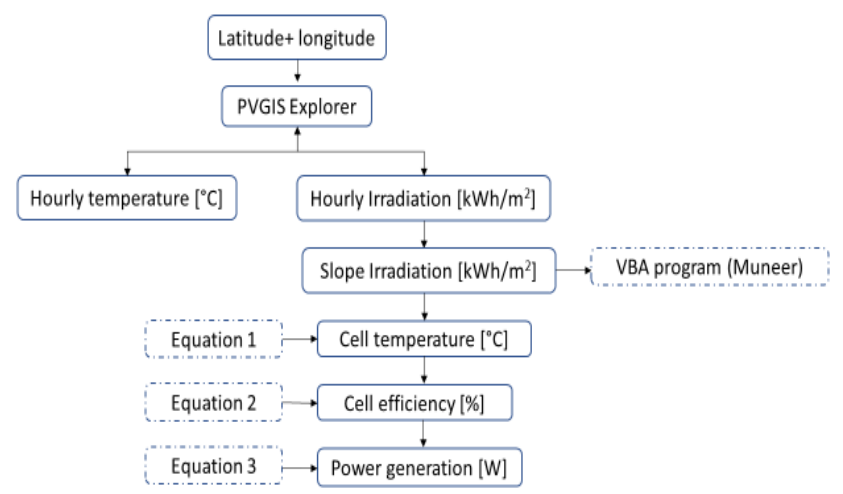

Fig .1 Calculation method for the power generation of one PV module. Modified from [7].

The cell temperature, efficiency and power generation of one photovoltaic module were calculated considering Equation 1, 2 and 3. Mainly, the factors are represented by the air temperature obtained from the PVGIS Explorer (Ta); global slope irradiation (Gslope); global radiation at the nominal operating cell temperature (Gnoct); nominal operating PV cell temperature (Tc, noct) [8]; cell efficiency at standard test conditions (nstc); absorptivity of the module (Ta); cell temperature at standard testing conditions (Tc, stc); temperature coefficient value ( $\alpha p$ ) [9]; electrical efficiency at standard test conditions ( $\eta \mathrm{mod})$ and area of the PV module surface (A). It is essential to note that some values of the formulas belong to the database of the PV module [10].

$$
\mathrm{Tc}=\mathrm{Ta}+\left(\frac{\text { Gslope }}{\text { Gnoct }}\right)(\mathrm{Tc}, \text { noct }-\mathrm{Ta} \text {, noct })\left(1-\left(\mathrm{n} \frac{\mathrm{stc}}{\mathrm{T} \alpha}\right)\right)\left[{ }^{\circ} \mathrm{C}\right]
$$
Eq .1: Cell temperature of PV panel [8].

$$
\eta c e l l=\eta s t c[1+\alpha p(T c-T c, s t c)][\%]
$$

Eq .2: Cell efficiency of a photovoltaic module [8].

$$
P=\eta \bmod * A * G t l t[1-0.0045 T c-298.15][W]
$$

Eq .3: Power generation of PV panel [7].

Then the solar farm is determined by the relation between the total electric demanded and the energy provided by a single PV panel. The last function is represented by Equation 4, where Am is the useful area of the photovoltaic module and Itilt is the tilted global irradiance.

$$
E \text { module }=A m * \eta s t c * \text { Itilt }[\mathrm{kWh} / \text { day }]
$$

Eq .4: Energy of one photovoltaic panel [11]

\section{Integration photovoltaic-fuel cell system}

Firstly, it was necessary to estimate the hydrogen consumption of the hybrid system. As a result, Equation 5 describes the factors involved, such as the yearly electric demand (E_demand); efficiency of the $\mathrm{PV}-\mathrm{H} 2-\mathrm{SOFC}$ system and higher heating value of the hydrogen (HHV).

$$
H 2_{\text {demand }}=\frac{E_{-} \text {demand }}{\text { Efficiency } * H H V}[\mathrm{~kg}]
$$

Eq .5: Amount of hydrogen required in the hybrid system [12].

After getting the energy demand, solar source and hydrogen consumption, it was possible to simulate the system by the FCPower model [13]. Additionally, it was necessary to include types of equipment data specification, such as from the PV panel, electrolyser [14] and fuel cell [15] used in the simulation. Details of the modelling process are explained in Fig. 2.

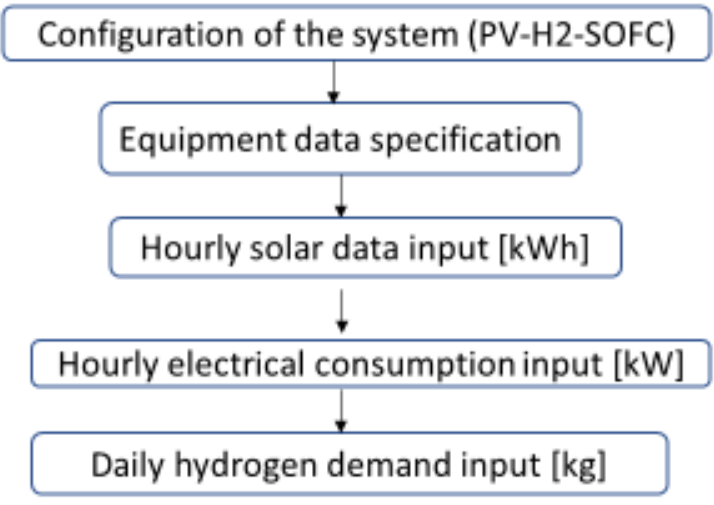

Fig .2 Flow diagram of the FCPower simulation according to the hybrid system configuration [7].

\section{RESULTS}

\section{A. Solar Radiation and Air Temperature}

According to the database from the photovoltaic geographical information system (PVGIS), the air temperature values consider the hourly temperature average of each month, corresponding to the year 2016. Notably, the maximum and minimum temperature variation during the year was in November and June with around $14^{\circ} \mathrm{C}$ and $9^{\circ} \mathrm{C}$ of difference, respectively. The result of the simulation is detailed in Table 1. 

http://dx.doi.org/10.21622/RESD.2019.05.2.057

Table 1 Summary of the Monthly Ambient Temperature [6]

\begin{tabular}{|c|c|c|c|}
\hline Month & Average $\left[{ }^{\circ} \mathbf{C}\right]$ & $\operatorname{Max}\left[{ }^{\circ} \mathbf{C}\right]$ & Min $\left[{ }^{\circ} \mathbf{C}\right]$ \\
\hline Jan & 30.83 & 37.7 & 25 \\
\hline Feb & 31.60 & 37.8 & 26.1 \\
\hline Mar & 29.46 & 35.1 & 24.3 \\
\hline Apr & 25.45 & 30.8 & 20.7 \\
\hline May & 20.89 & 26.2 & 16.4 \\
\hline Jun & 17.16 & 22 & 13.5 \\
\hline Jul & 16.09 & 21.2 & 12 \\
\hline Aug & 18.22 & 24 & 13.2 \\
\hline Sep & 20.10 & 26.1 & 14.5 \\
\hline Oct & 23.58 & 30.2 & 17.2 \\
\hline Nov & 26.03 & 33 & 19.4 \\
\hline Dec & 28.59 & 35.4 & 22 \\
\hline
\end{tabular}

Analogously, the simulation provides hourly and monthly global horizontal radiation. Table 2 indicates that during December produce the highest solar potential with over $800\left[\mathrm{~W} / \mathrm{m}^{2}\right]$, between the 11 and 15 hours. In contrast, the lowest radiation was in wintertime (June and July), with less of $200\left[\mathrm{~W} / \mathrm{m}^{2}\right]$.

\section{B. Cell Temperature, Efficiency and Output Power}

Based on the air temperature values, factors and formulas it was possible to obtain the monthly and hourly cell temperature. The result per month showed that the PV panel increases the heat during the summer season, approximately $2^{\circ} \mathrm{C}$. At the same time, Fig. 3 describes the result per hour, where the rise appears in the afternoon, with around $3^{\circ} \mathrm{C}$ of difference.

Table 2 Average of the Global Radiation Per Hour and Month [W/ $\left./ \mathrm{m}^{2}\right]$

\begin{tabular}{|c|c|c|c|c|c|c|c|c|c|c|c|c|}
\hline $\begin{array}{l}\text { Hour } / \mathrm{m} \\
\text { onth }\end{array}$ & Jan & Feb & Mar & Apr & May & Jun & Jul & Aug & Sept & Oct & Nov & Dec \\
\hline 0 & 0 & 0 & 0 & 0 & 0 & 0 & 0 & 0 & 0 & 0 & 0 & 0 \\
\hline 1 & 0 & 0 & 0 & 0 & 0 & 0 & 0 & 0 & 0 & 0 & 0 & 0 \\
\hline 2 & 0 & 0 & 0 & 0 & 0 & 0 & 0 & 0 & 0 & 0 & 0 & 0 \\
\hline 3 & 0 & 0 & 0 & 0 & 0 & 0 & 0 & 0 & 0 & 0 & 0 & 0 \\
\hline 4 & 0 & 0 & 0 & 0 & 0 & 0 & 0 & 0 & 0 & 0 & 0 & 0 \\
\hline 5 & 0 & 0 & 0 & 0 & 0 & 0 & 0 & 0 & 0 & 0 & 0 & 0 \\
\hline 6 & 0 & 0 & 0 & 0 & 0 & 0 & 0 & 0 & 0 & 0 & 27 & 22 \\
\hline 7 & 47 & 8 & 8 & 0 & 0 & 0 & 0 & 0 & 15 & 95 & 188 & 194 \\
\hline 8 & 129 & 185 & 210 & 72 & 56 & 49 & 46 & 60 & 201 & 376 & 537 & 567 \\
\hline 9 & 124 & 257 & 263 & 141 & 64 & 52 & 51 & 89 & 254 & 412 & 560 & 578 \\
\hline 10 & 157 & 385 & 396 & 245 & 123 & 75 & 88 & 186 & 374 & 547 & 690 & 722 \\
\hline 11 & 163 & 488 & 495 & 331 & 191 & 129 & 153 & 264 & 460 & 639 & 777 & 821 \\
\hline 12 & 160 & 552 & 550 & 375 & 235 & 169 & 198 & 313 & 506 & 684 & 821 & 865 \\
\hline 13 & 162 & 564 & 564 & 386 & 237 & 176 & 204 & 323 & 511 & 682 & 817 & 864 \\
\hline 14 & 173 & 517 & 535 & 354 & 210 & 152 & 184 & 296 & 472 & 631 & 764 & 821 \\
\hline 15 & 191 & 425 & 468 & 290 & 150 & 101 & 132 & 235 & 398 & 541 & 667 & 719 \\
\hline 16 & 162 & 344 & 360 & 196 & 86 & 77 & 82 & 149 & 293 & 417 & 544 & 608 \\
\hline 17 & 134 & 219 & 224 & 92 & 50 & 37 & 46 & 71 & 170 & 271 & 396 & 465 \\
\hline 18 & 92 & 125 & 104 & 19 & 0 & 0 & 0 & 15 & 47 & 108 & 224 & 304 \\
\hline 19 & 38 & 20 & 0 & 0 & 0 & 0 & 0 & 0 & 0 & 0 & 1 & 90 \\
\hline 20 & 0 & 0 & 0 & 0 & 0 & 0 & 0 & 0 & 0 & 0 & 0 & 0 \\
\hline 21 & 0 & 0 & 0 & 0 & 0 & 0 & 0 & 0 & 0 & 0 & 0 & 0 \\
\hline 22 & 0 & 0 & 0 & 0 & 0 & 0 & 0 & 0 & 0 & 0 & 0 & 0 \\
\hline 23 & 0 & 0 & 0 & 0 & 0 & 0 & 0 & 0 & 0 & 0 & 0 & 0 \\
\hline
\end{tabular}

On the other hand, the relationship between the PV, the cell temperature and the cell efficiency are represented by Fig. 4 and 5 . Principally, this last variable decreases during summer (January and
February) with $15 \%$ less. Furthermore, the period with the lowest performance was between 13 and 15 hours, with almost $14.7 \%$ at $9^{\circ} \mathrm{C}$. 


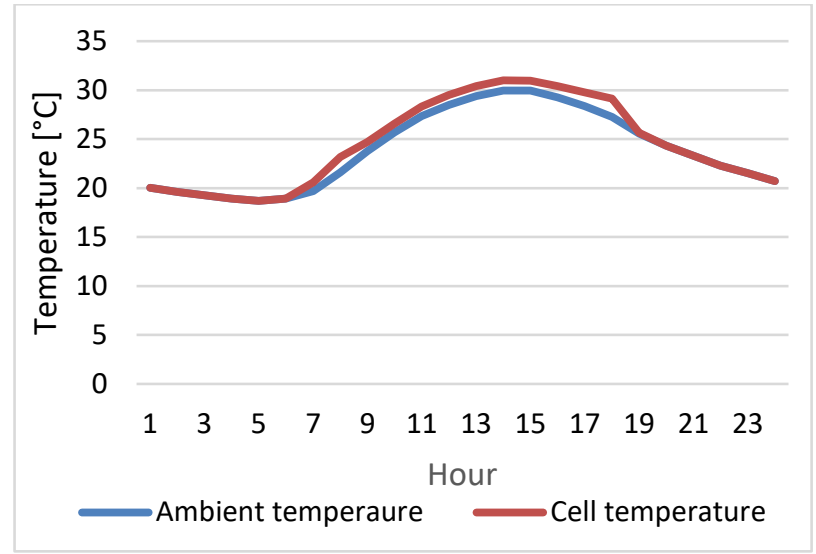

At the same time, the power generation of the photovoltaic panel was calculated per hour and month, with results manifested in Table 3 . Overall, the peak is concentred in intervals during mornings and evenings of the summer season. For example, December shows the highest power production at the 8 and 18 hours, with 221 and $284 \mathrm{~W}$, respectively. In the rest of the months, the same variation exists but with a lower outpower.

Fig .3 Average of ambient and cell temperature per hour.

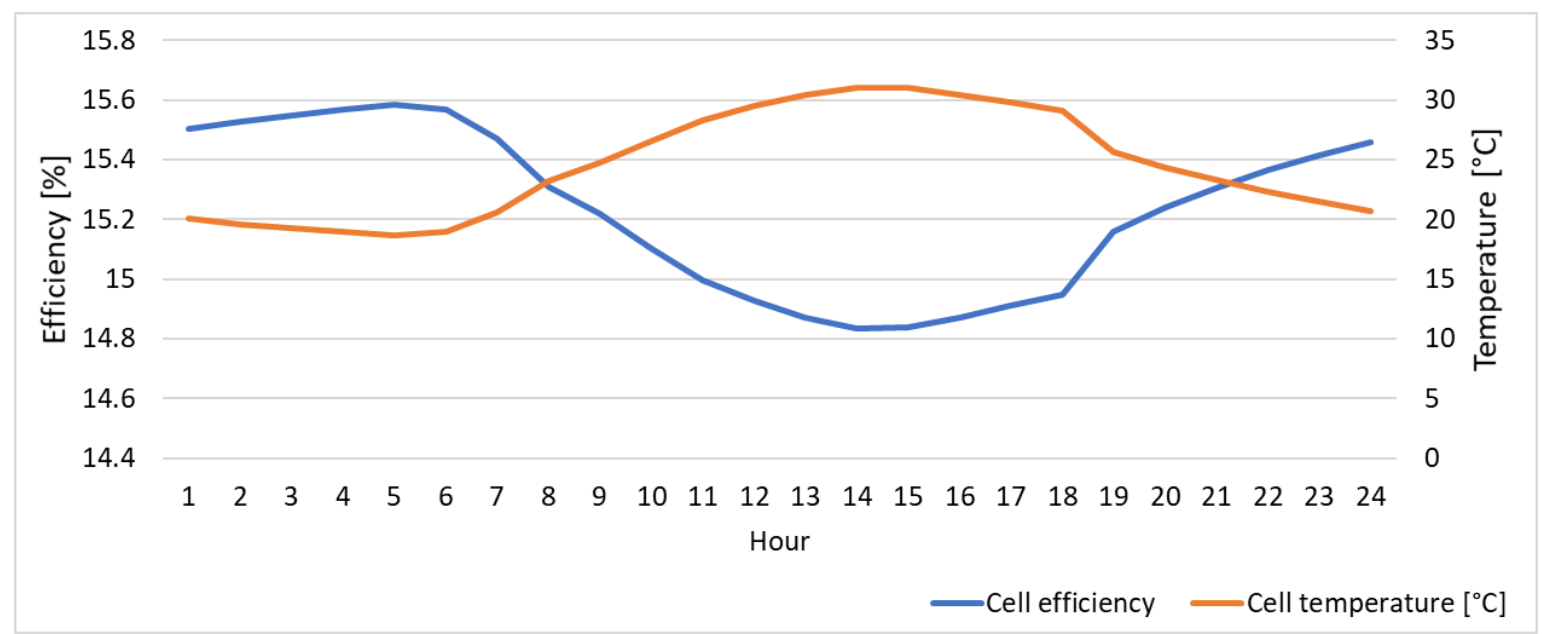

Fig .4 Cell temperature and Efficiency per month.

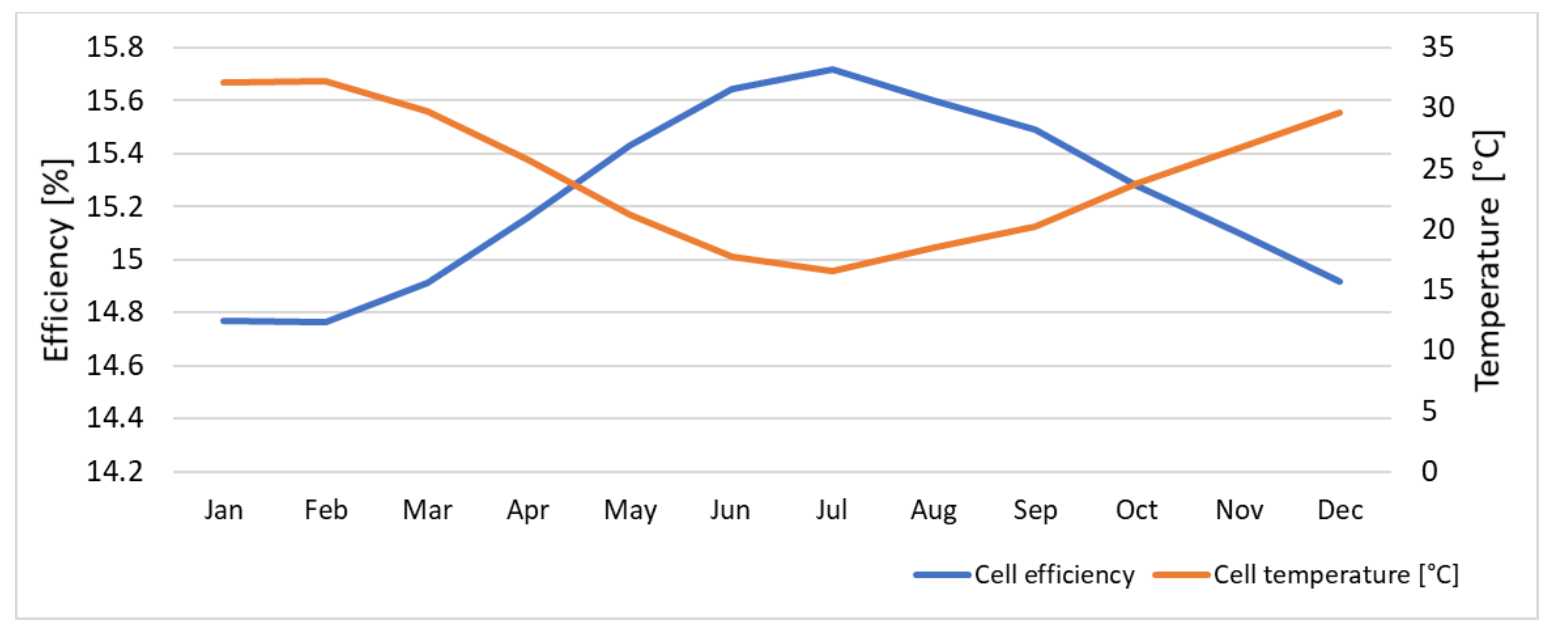

Fig .5 Average of the cell temperature and efficiency per hour.

\section{Determination of PV System}

Regarding the results calculated previously, it was possible to obtain the PV modules quantity required in the hybrid system. In this case, the annual electric demand extracted from the simulator plan of Australian energy consumption was of $4610 \mathrm{kWh}$. Additionally, the energy produced by one photovoltaic module was of $89.43 \mathrm{kWh} /$ year. As a result, the total of modules was of 52. Details are in Table 4.

The energy generation of the solar farm was calculated considering the number of $\mathrm{PV}$ panels required, and the energy produced by a single 

http://dx.doi.org/10.21622/RESD.2019.05.2.057

photovoltaic module. This last find was around $90 \mathrm{kWh} /$ year. In contrast, the global supplied was of $4659 \mathrm{kWh} / \mathrm{year}$, which includes the energy generation of $52 \mathrm{PV}$ panels. As Table 5 shows, the month with the highest energy production was December with 996kWh, and the lowest was June with 162kWh.
Table 4 Summary of the Monthly Ambient Temperature [6]

\begin{tabular}{|c|c|c|c|}
\hline $\begin{array}{c}\text { E panel } \\
\mathrm{kWh} / \text { day }\end{array}$ & $\begin{array}{c}\text { E panel } \\
\mathrm{kWh} / / \mathrm{yr} .\end{array}$ & $\begin{array}{c}\text { Total } \\
\text { consumption } \\
, \mathrm{kWh} / \mathrm{yr} .\end{array}$ & PV panels \\
\hline 0.245 & 89.43 & 4610 & 52 \\
\hline
\end{tabular}

Table 3 PV Module Output Power [W].

\begin{tabular}{|c|c|c|c|c|c|c|c|c|c|c|c|c|}
\hline $\begin{array}{l}\text { Month/ } \\
\text { Hour }\end{array}$ & Jan & Feb & Mar & Apr & May & Jun & Jul & Aug & Sep & Oct & Nov & Dec \\
\hline 1 & 0.0 & 0.0 & 0.0 & 0.0 & 0.0 & 0.0 & 0.0 & 0.0 & 0.0 & 0.0 & 0.0 & 0.0 \\
\hline 2 & 0.0 & 0.0 & 0.0 & 0.0 & 0.0 & 0.0 & 0.0 & 0.0 & 0.0 & 0.0 & 0.0 & 0.0 \\
\hline 3 & 0.0 & 0.0 & 0.0 & 0.0 & 0.0 & 0.0 & 0.0 & 0.0 & 0.0 & 0.0 & 0.0 & 0.0 \\
\hline 4 & 0.0 & 0.0 & 0.0 & 0.0 & 0.0 & 0.0 & 0.0 & 0.0 & 0.0 & 0.0 & 0.0 & 0.0 \\
\hline 5 & 0.0 & 0.0 & 0.0 & 0.0 & 0.0 & 0.0 & 0.0 & 0.0 & 0.0 & 0.0 & 0.0 & 0.0 \\
\hline 6 & 0.0 & 0.0 & 0.0 & 0.0 & 0.0 & 0.0 & 0.0 & 0.0 & 0.0 & 0.0 & 2.6 & 2.0 \\
\hline 7 & 71.9 & 14.8 & 2.2 & 0.0 & 0.0 & 0.0 & 0.0 & 0.0 & 5.6 & 36.9 & 138.8 & 165.7 \\
\hline 8 & 164.1 & 67.5 & 25.7 & 16.1 & 20.6 & 17.9 & 16.8 & 20.6 & 30.6 & 39.9 & 139.6 & 220.6 \\
\hline 9 & 84.5 & 35.9 & 29.3 & 22.1 & 18.8 & 19.1 & 18.7 & 15.5 & 28.0 & 40.9 & 50.3 & 111.1 \\
\hline 10 & 50.5 & 45.8 & 37.2 & 30.6 & 21.7 & 22.7 & 21.7 & 23.7 & 38.2 & 49.1 & 48.4 & 61.5 \\
\hline 11 & 53.7 & 49.1 & 42.5 & 37.6 & 27.0 & 25.7 & 26.7 & 28.0 & 39.9 & 49.4 & 50.1 & 50.4 \\
\hline 12 & 52.7 & 50.1 & 42.5 & 37.9 & 32.3 & 30.3 & 31.0 & 31.3 & 39.5 & 49.8 & 49.8 & 53.1 \\
\hline 13 & 53.4 & 51.7 & 45.1 & 39.9 & 31.3 & 30.6 & 30.3 & 31.3 & 39.9 & 49.8 & 51.7 & 54.4 \\
\hline 14 & 57.0 & 55.7 & 48.8 & 38.6 & 31.0 & 29.7 & 31.0 & 30.0 & 37.6 & 51.4 & 53.4 & 56.0 \\
\hline 15 & 58.3 & 58.7 & 46.1 & 36.6 & 26.4 & 25.0 & 27.0 & 28.0 & 34.3 & 47.8 & 53.4 & 68.9 \\
\hline 16 & 100.8 & 49.8 & 38.9 & 29.0 & 22.4 & 28.0 & 24.7 & 22.7 & 29.3 & 40.9 & 53.3 & 117.5 \\
\hline 17 & 158.4 & 66.2 & 31.0 & 18.5 & 17.9 & 13.5 & 17.2 & 18.8 & 25.0 & 32.3 & 109.2 & 182.8 \\
\hline 18 & 249.2 & 131.3 & 19.8 & 8.4 & 0.0 & 0.0 & 0.0 & 6.9 & 15.4 & 42.2 & 172.4 & 283.6 \\
\hline 19 & 21.5 & 9.9 & 0.0 & 0.0 & 0.0 & 0.0 & 0.0 & 0.0 & 0.0 & 0.0 & 0.0 & 18.1 \\
\hline 20 & 0.0 & 0.0 & 0.0 & 0.0 & 0.0 & 0.0 & 0.0 & 0.0 & 0.0 & 0.0 & 0.0 & 0.0 \\
\hline 21 & 0.0 & 0.0 & 0.0 & 0.0 & 0.0 & 0.0 & 0.0 & 0.0 & 0.0 & 0.0 & 0.0 & 0.0 \\
\hline 22 & 0.0 & 0.0 & 0.0 & 0.0 & 0.0 & 0.0 & 0.0 & 0.0 & 0.0 & 0.0 & 0.0 & 0.0 \\
\hline 23 & 0.0 & 0.0 & 0.0 & 0.0 & 0.0 & 0.0 & 0.0 & 0.0 & 0.0 & 0.0 & 0.0 & 0.0 \\
\hline 24 & 0.0 & 0.0 & 0.0 & 0.0 & 0.0 & 0.0 & 0.0 & 0.0 & 0.0 & 0.0 & 0.0 & 0.0 \\
\hline
\end{tabular}

The design of $\mathrm{PV}$ facilities is composed of six rows and seven columns of panels with $45^{\circ}$ inclination and orientated towards the north. Nevertheless, to reduce the shadow risk, the PV arrows have a prudent distance between them. Furthermore, the sizing of PV array considers two inventers for the total of modules. Fig. 7 shows the solar farm involved and location. Principally, the area distribution includes two aspects; the first one is a useful area that represents the location of the panels, with $322 \mathrm{~m}^{2}$. The second factor is around $30 \%$ more surface $\left(419 \mathrm{~m}^{2}\right)$ intended to a maintenance purpose in the system.

Similarly, Fig. 6 illustrates the distribution of energy consumption and the energy supplied. The electric demand showed steady rises and drops. However, there are significant leaps of the energy provided by the solar system, especially in December. Comparatively, during wintertime, the energy demand was higher than the produced. However, this has switched drastically in summer.

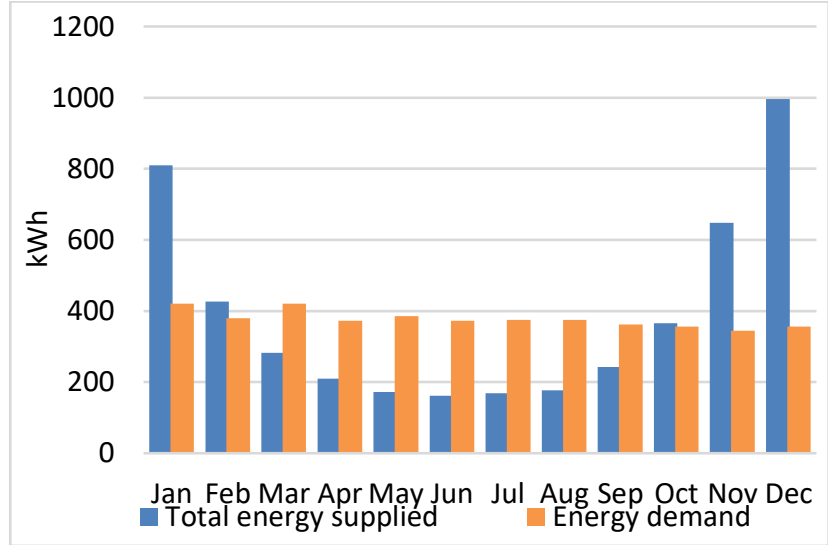

Fig .6 Comparison between the energy demand and the energy supplied by the solar farm.

The array size involves a voltage dimension of $60 \mathrm{~V}$ and $49 \mathrm{~V}$ for the respective maximum and minimum open circuit voltage. Furthermore, the maximum current in the photovoltaic module was of $8.4 \mathrm{~A}$. Analogously, the interval of $\mathrm{PV}$ modules per string was between 10 and 5 , considering a maximum of voltage and current per line of $600 \mathrm{~V}$ and $18 \mathrm{~A}$, respectively. The design of $P V$ facilities is composed of six rows and 
seven columns of panels with $45^{\circ}$ inclination and orientated towards the north. Nevertheless, to reduce the shadow risk, the PV arrows have a prudent distance between them. Furthermore, the sizing of PV array considers two inventers for the total of modules. Fig. 7 shows the solar farm involved and location. Principally, the area distribution includes two aspects; the first one is a useful area that represents the location of the panels, with $322 \mathrm{~m}^{2}$. The second factor is around $30 \%$ more surface $\left(419 \mathrm{~m}^{2}\right)$ intended to a maintenance purpose in the system.

Table 5 Summary of Output Energy of Photovoltaic Module.

\begin{tabular}{|c|c|c|}
\hline Month & $\begin{array}{c}\text { Energy single } \\
\text { module } \\
\text { supplied [kWh] }\end{array}$ & $\begin{array}{c}\text { Total Energy } \\
\text { module } \\
\text { supplied [kWh] }\end{array}$ \\
\hline Jan & 15.57 & 809.8 \\
\hline Feb & 8.21 & 426.9 \\
\hline Mar & 5.42 & 281.8 \\
\hline Apr & 4.04 & 210.0 \\
\hline May & 3.3 & 171.7 \\
\hline Jun & 3.10 & 161.7 \\
\hline Jul & 3.25 & 168.8 \\
\hline Aug & 3.40 & 176.9 \\
\hline Sep & 4.66 & 242.1 \\
\hline Oct & 7.02 & 365.1 \\
\hline Nov & 12.47 & 648.4 \\
\hline Dec & 19.15 & 995.5 \\
\hline Total & 89.589 & 4658.678 \\
\hline
\end{tabular}

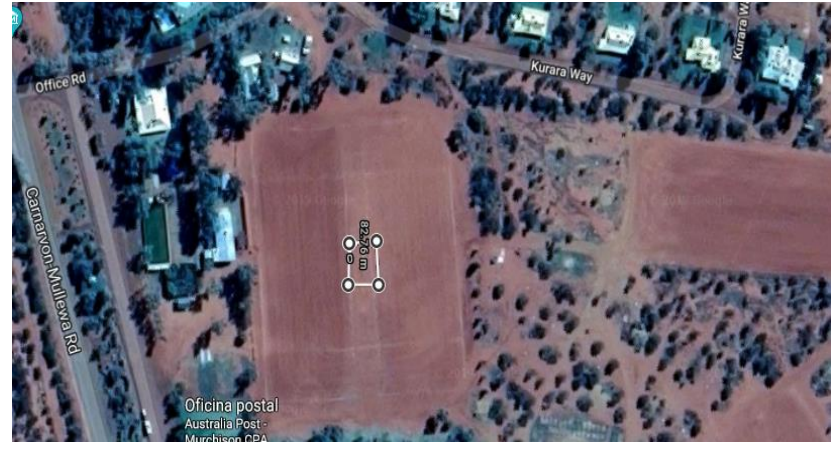

Fig .7 Location of solar farm. Source: (Google earth, 2019).

\section{Configuration of the PV-H2-SOFC System.}

The first stage of the hybrid system design involves the solar energy that provides electric generation and hydrogen for the fuel cell system. However, if the hydrogen production is not enough to supply the demand of the system, it is necessary to add the missing hydrogen from an external source. As a result, the PV-H2-SOFC configuration has two parties, one from solar energy providing the hydrogen partially to the electrolyser, and the other from the hydrogen storage. As Fig. 8 describes, the first scenario exists when the PV generation is lower than the energy consumption.

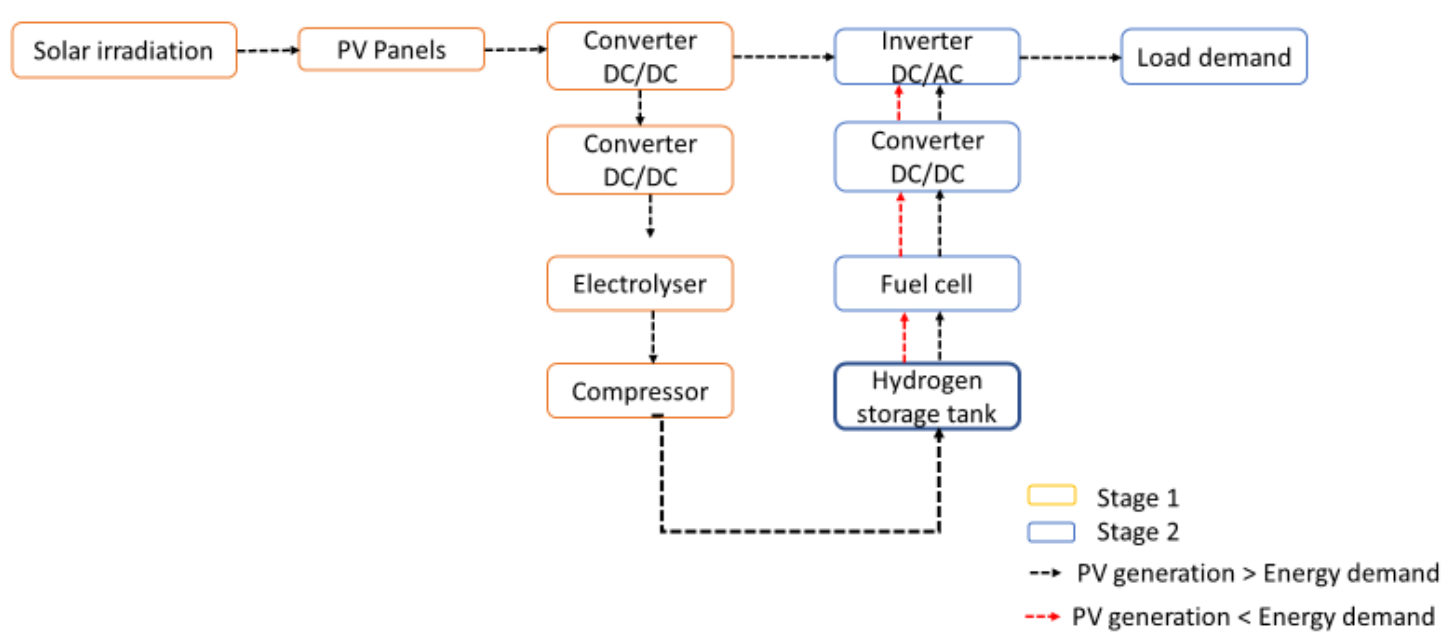

Fig .8 Design of PV-H2-SOFC system [7].

Based on the hydrogen calculation and the energy consumption, it was possible to get the comparative variation between both requirements. As Fig. 9 describes, the energy demand is proportional to the hydrogen consumption of the fuel cell. For example, the highest and lowest demand for hydrogen and electricity are during summer and spring, respectively. The range of both periods is between $660-780 \mathrm{~m}^{3}$ for the hydrogen and $1050-1200 \mathrm{kWh}$ for electric consumption.
On the other hand, according to the results of the hydrogen produced from PV generation and the hydrogen required, the deficit of hydrogen of the hybrid system was determined. In this case, the highest gap was in the wintertime, with $17.98 \mathrm{~kg}$ missing hydrogen. In contrast, in the months of summer presented the lowest variation, with a deficit of $9.86 \mathrm{~kg}$. The hydrogen distribution is described in Fig. 10. 


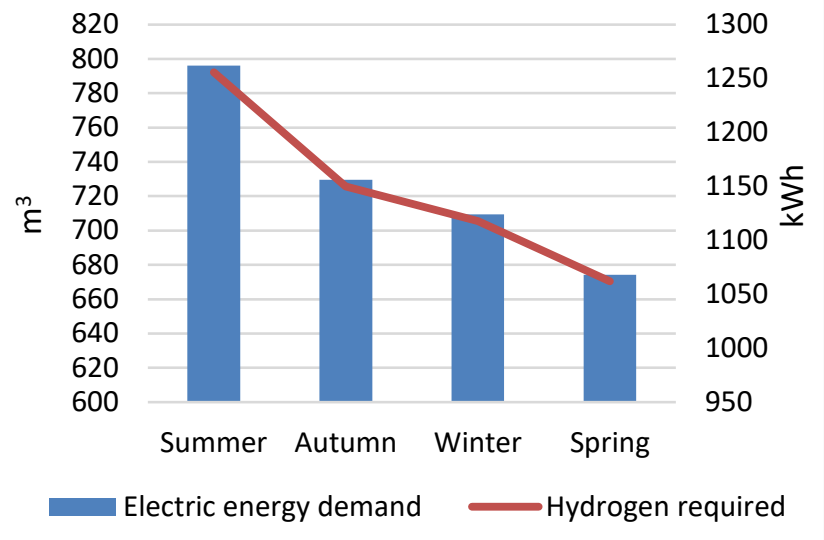

Fig .9 Hydrogen demand and electricity required per season.

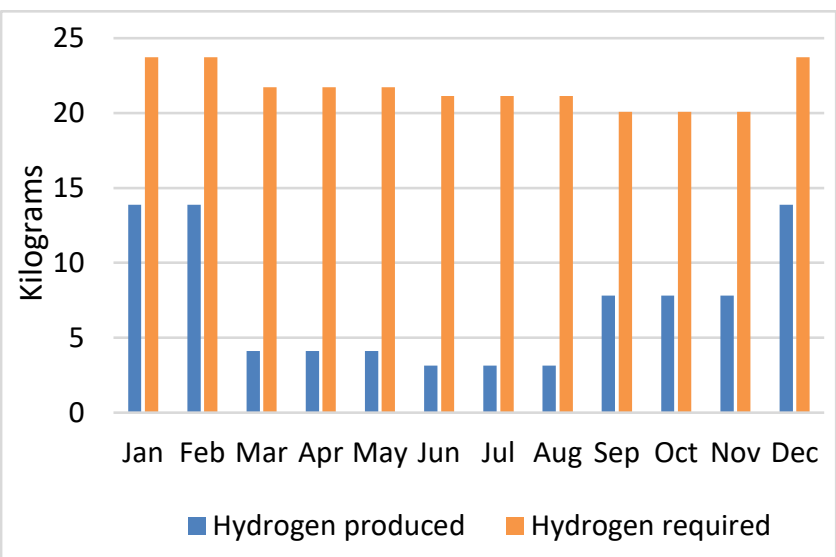

Fig .10 Hydrogen demand and hydrogen deficit per month.

The storage tank was dimensioned considering the highest deficit of hydrogen of the year $(18 \mathrm{~kg} /$ month and $200 \mathrm{~m}^{3} /$ month) and the values of volume and pressure of the electrolyser and tank. As a consequence, the hydrogen pressurised was $30.8 \mathrm{~m}^{3}$, but for safety reasons, it must include a $10 \%$ of volume [16], with a final dimension tank of $33.88 \mathrm{~m}^{3}$. It is important to note that the location of the tank was underground due to the reduced risk of temperature fluctuation [7].

\section{E. Simulation Results.}

The FCPower model provided the modelling results of the PV-H2-SOFC system, which started with the annual input specifications data, such as the solar capacity factor and the amount of fuel used in the fuel cell. For example, the yearly system energy output used onsite is the balance between the delivered of electricity $(4567 \mathrm{kWh})$, heat $(0 \mathrm{kWh})$, hydrogen (8763kWh), and grid electricity to the building ( $0 \mathrm{kWh})$. Details of those values are presented in Table 6 .
Table 6 Energy Input of the System, from FCPower Model Simulation

[13].

\begin{tabular}{|c|c|}
\hline Values & Specifications \\
\hline 86.801 & Fuel used in FCS [kWh/kWh] \\
\hline 0.000 & Fuel used in burner $[\mathrm{kWh} / \mathrm{kWh}]$ \\
\hline 0.349 & AC from solar $[\mathrm{kWh} / \mathrm{kWh}]$ \\
\hline 0.000 & AC from wind $[\mathrm{kWh} / \mathrm{kWh}]$ \\
\hline 0.000 & Purchased Grid Electricity [kWh/kWh] \\
\hline $0.0 \%$ & $\begin{array}{c}\text { Purchased grid electricity cost }(\mathrm{wtd} \text { avg \% of } \\
\text { base cost) }\end{array}$ \\
\hline 13,331 & $\begin{array}{c}\text { System Energy Output Used Onsite per Year } \\
\text { [kWh] }\end{array}$ \\
\hline
\end{tabular}

At the same time, the model provides the general specification of the fuel cell, considering the range of energy capacity $53.3 \mathrm{kWh}$; combined heat, hydrogen, and power efficiency of 63\%; fuel consumed for combined heat and power of $132 \mathrm{kWh}$ and the maximum hydrogen generation of $17 \mathrm{~kW}$. Table 7 shows the data specification of the SOFC system.

Table 7 Summary of the Fuel Cell Specifications Per Hour [13].

\begin{tabular}{|c|c|c|}
\hline Specification & Value & Units \\
\hline Electricity Produced & 53.33 & $\mathrm{~kW}$ \\
\hline $\begin{array}{c}\text { Electrical CHP efficiency at current } \\
\text { electrical power level }\end{array}$ & 0.4047 & $\mathrm{~kW} / \mathrm{kW}$ \\
\hline $\begin{array}{c}\text { Total CHP efficiency at current } \\
\text { electrical power level }\end{array}$ & 0.6273 & $\mathrm{~kW} / \mathrm{kW}$ \\
\hline Fuel used for CHP operations & 131.8 & $\mathrm{~kW}$ \\
\hline CHP heat total & 29.3 & $\mathrm{~kW}$ \\
\hline Max H2 production ability & 17.0 & $\mathrm{~kW}$ \\
\hline Max H2 over-production ability & 11.4 & $\mathrm{~kW}$ \\
\hline H2 production & 0.0 & $\mathrm{~kW}$ \\
\hline CHP heat used for H2 production & 0.0 & $\mathrm{~kW}$ \\
\hline CHP heat out total & 29.3 & $\mathrm{~kW}$ \\
\hline Over-production of H2 & 0.0 & $\mathrm{~kW}$ \\
\hline Fuel used for H2 over-production & 0.0 & $\mathrm{~kW}$ \\
\hline Total fuel consumption & 131.8 & $\mathrm{~kW}$ \\
\hline
\end{tabular}

The hourly output results showed that the electricity delivery was of $0.343 \mathrm{kWh}$ per $\mathrm{kWh}$ produced by the hybrid system. Besides, the hydrogen delivery was $0.657 \mathrm{kWh} / \mathrm{kWh}$, which represents the relation between the hydrogen delivered and the yearly system energy output used onsite. Analogously, the electricity sold to the grid includes the results of the energy input (13331kWh/year), and the excess of energy intended to the grid $(477827 \mathrm{kWh})$. Table 8 details the total of power supplied by the PV-H2-SOFC system (491158kWh), which considers the values of electricity generated, energy sold, hydrogen production and heat delivered. 
Table 8 Energy Output of the System, from FCPower Model Simulation [13].

\begin{tabular}{|c|c|}
\hline Values & Specifications \\
\hline 0.343 & AC Delivered $[\mathrm{kWh} / \mathrm{kWh}]$ \\
\hline 0.000 & Heat Delivered $[\mathrm{kWh} / \mathrm{kWh}]$ \\
\hline 0.657 & Hydrogen Delivered $[\mathrm{kWh} / \mathrm{kWh}]$ \\
\hline $3.58 \mathrm{E}+01$ & AC sold to grid $[\mathrm{kWh} / \mathrm{kWh}]$ \\
\hline 491,158 & Total Energy Supplied per Year $[\mathrm{kWh}]$ \\
\hline
\end{tabular}

Finally, the simulation provided different types of efficiencies as explained in Fig. 11. Principally, the fuel cell efficiency was higher than the electrical performance; for example, in the operating fraction 0.5 , the capabilities were $70 \%$ and $45 \%$, respectively. Furthermore, the capacities of the categories of hydrogen-fuel-cell and electrolyser were significantly similar, with around $52 \%$ of the performance at $100 \%$ of operation.

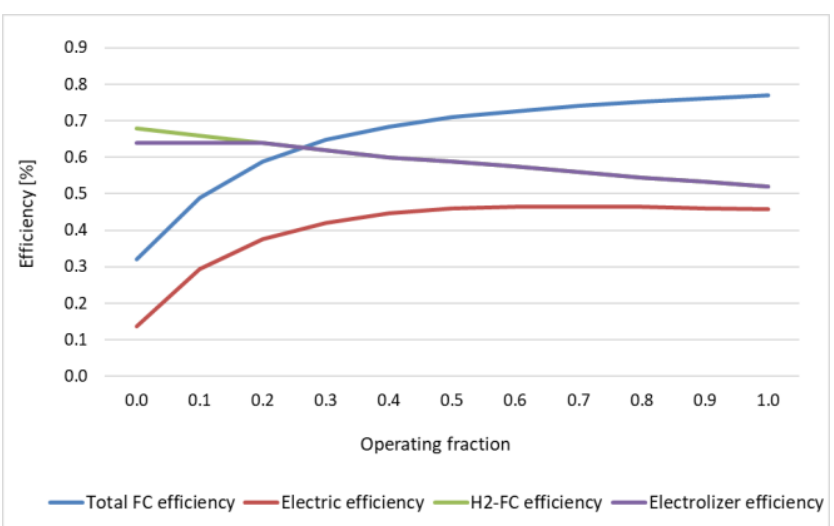

Fig .11 Performance of PV-H2-SOFC system. Modified from [13].

\section{ECONOMIC ANALYSIS}

According to financial results obtained from FCPower model simulation, the price factors of system net electricity and hydrogen were $0.133 \$ / \mathrm{kWh}$ and 35.7 $\$ / \mathrm{kWh}$, respectively. As a result, considering 4567 $\mathrm{kWh} /$ year of electricity production from the hybrid system and $8763 \mathrm{kWh}$ of hydrogen required, the total cost of energy generation was 313,446 \$/year. However, this cost can be reduced, considering the system electricity sold to the grid of $38,912 \$$ /year, whose values includes $477,827 \mathrm{kWh} /$ year of excess and the sold price factor of $0.081 \$ / \mathrm{kWh}$. The total cost obtained was 274,534 \$/year. Analogously, the Australian electricity load price is around $0.22 \$ / \mathrm{kWh}$ [17], which involves a total value of $913 \$$ year.

Overall, the electricity cost from the hybrid system was competitive compared to the grid (around 33\% cheaper). Nonetheless, the deficit of hydrogen increases is considerable to the global cost.

On the other hand, one of the main advantages of fuel cell integration was the elimination electric battery into the hybrid system configuration due to the water electrolysis can solve the irregularity of solar availability. Therefore, its elimination helps to decrease the operational cost by around 30\% [7].

\section{CONCLUSION}

According to the solar power generation, hydrogen and fuel cell modelling, the hybrid system is a viable alternative to supply the electric consumption of one house. Therefore, the following points summarise the findings:

- The Western territory of Australia showed an elevated solar source, considering that the highest daily average was in December with a global radiation of $318 \mathrm{~W} / \mathrm{m}^{2}$. The rest of the months presented a slight difference between them.

- The hourly variation between the cell efficiency and panel temperature did not change significantly as the performance was reduced by $0.2 \%$ in the 13 hours. However, the monthly results showed that the efficiency decreased by $1 \%$ during summertime.

- The solar farm can supply the total annual demand. Nevertheless, the distribution of electricity generation was significantly unequal. For example, in the wintertime, solar energy only provides $47 \%$ of the total consumption required. As importantly, the integration of the fuel cell helps to supply this deficit.

- The electricity generation increases by more than $30 \%$ with the integration of the fuel cell. Specifically, the photovoltaic energy produced $4658 \mathrm{kWh} /$ year, and the solid oxide fuel cell generated $4567 \mathrm{kWh} /$ year of electricity load and $477827 \mathrm{kWh} /$ year of delivered to the grid. As a result, both renewables sources are $9225 \mathrm{kWh} /$ year, which represents $50 \%$ more than the energy demand.

- The hybrid system presented different efficiencies stages and as a result there are electric and heat losses (unrecoverable energy), associated with 
electrical efficiency and total fuel cell efficiency, respectively. In this case, the fuel cell performance is $42 \%$ higher than the electric efficiency.

- As a result, the PV-H2-SOFC system allows supply a higher electric demand and adds thermal consumption as hot water. Furthermore, it has cogeneration benefits, such as the environmental impact due to hydrogen obtained from PV panels, which is used in the fuel cell. Also, in this process, there is heat recovery, so it is a closed energy cycle.

- Despite that the integration of fuel cell into PV system showed an economic disadvantage, there is financial retribution for the sale of the surplus energy, improving the energy cost balance. Besides, the system can supply a higher demand for the same cost, considering, for example, thermal energy consumption.

\section{REFERENCES}

[1] G. Bourne, P. Scrock, and A. Stock. "Powering progress: States renewable energy race," 16 Oct 2018. [Online]. Available: https://www.climatecouncil.org.au/resources/stat es-renewable-energy/. [Accessed 3 Jun 2019].

[2] L. Brailsford, A. Stock, G. Bourne, and P. Stock. "Powering progress: States renewable energy race," Climate Council of Australia, 2018.

[3] e. a. t. (Australian Government Department of Resources, G. Australia and A. B. o. A. a. R. Economics, "Australian energy resource assessment," 2010. [Online]. Available: https://d28rz98at9flks.cloudfront.net/70142/7014 2_complete.pdf. [Accessed 4 June 2019].

[4] S. Bruce, M. Temminghoff, J. Hayward, E. Schmidt, C. Munnings, D. Palfreyman, and P. Hartley. "National Hydrogen Roadmap: Pathways to an economically sustainable hydrogen industry in Australia," CSIRO, 2018.

[5] Australian Energy Regulator. "Energy made easy- Understand and compare your home energy usage," Australian Government, 24 April 2019. [Online]. Available: https://www.energymadeeasy.gov.au/benchmar k. [Accessed 16 May 2019].

[6] European Commission. "Photovoltaic geographical information system," 21 Sept 2017. [Online]. Available: http://re.jrc.ec.europa.eu/pvg_tools/en/tools.html . [Accessed 19 May 2019].

[7] S. Allende. "Energy analysis of a solid oxide fuel cell (Sofc) operated by PV system in the residential sector, in Highland," M.A. thesis, GRIN Verlag, Munich, 2018.

[8] F. Brihmat, and S. Mekhtoub, "PV cell temperature/ PV power output relationships homer methodology calculation," National Superior Polytechnic School, Algeria, 2014.

[9] M. Jeffrey, I. Kelly, T. Muneer, and I. Smith. "Evaluation of Solar Modelling Techniques Through Experiment on a $627 \mathrm{kWp}$ Photovoltaic," Journal of Renewable and Sustainable Energy, vol. 7, no. 3, 2105

[10] Advanced Solar Photonics. "ASP-400GSM smart moduletm series - high efficiency frameless monocrystalline solar modules," 2012. [Online]. Available: https://www.enfsolar.com/Product/pdf/Crystallin e/50bd9203a2fc0.pdf. . [Accessed 20 May 2019].

[11] T. Muneer, R. Milligan, I. Smith, A. Doyle, M. Pozuelo, and M. Knez. "Energetic, environmental and economic performance of electric," Edinburgh, Transportation Research Part D: Transport and Environment, 2015, pp. 40-61.

[12] A. Kabza. "Fuel cell formulary," 9 Nov 2016. [Online]. Available: http://www.pemfc.de/FCF_A4.pdf. [Accessed 21st May 2019].

[13] D. Steward. "National renewable energy laboratory," FCPower model simulation, 2013. [Online]. Available: https://www.nrel.gov/hydrogen/fuel-cell-powermodel.html. [Accessed 5 May 2019].

[14] A. El-Maaty. "Modelling and Simulation of a 
Photovoltaic Fuel Cell Hybrid System," PhD. thesis, University of Kassel , Kassel, 2005.

[15] Battelle Memorial Institute, "Manufacturing cost analysis of 100 and $250 \mathrm{~kW}$ fuel cell systems for primary power and combined heat and power applications," U.S. Department of Energy, 2016.

[16] T. Yuan, Q. Duan, X. Chen, X. Yuan, W. Cao, J. $\mathrm{Hu}$, and Q. Zhu. "Coordinated control of a windMethanol-Fuel cell system with hydrogen storage," MDPI, Basel, 2017.

[17] S. Downes. "Perth electricity prices compared," 7 Jan 2019. [Online]. Available: https://www.canstarblue.com.au/electricity/perth -electricity-prices/. [Accessed 1 Aug 2019].

[18] D. Goos. "Feasibility Study of a Solar Charging Facility for Electric Vehicles in Munich," M.A. thesis, Edinburgh, 2015.

[19] L. Parry. "Greener Kirkcaldy," 2015. [Online]. Available:

http://www.greenerkirkcaldy.org.uk/how-muchenergy-are-your-home-appliances-using/. [Accessed 13 May 2018].

[20] ACS Chemistry for life. "The energy efficiency of heating water," [Online]. Available: http://highschoolenergy.acs.org/content/hsef/en/ how-can-energy-change/energy-efficiency-ofheating-water.html. [Accessed 17 June 2018].

[21] E. Gago, S. Etxebarria, Y. Tham, Y. Aldali, and T. Muneer. "Inter-relationship between meandaily irradiation and temperature, and decomposition models for hourly irradiation and temperature," International Journal of LowCarbon Technologies, vol. 6, no. 1, pp. 22-37, 2010.

[22] A. Ganguly, D. Misra, and S. Ghosh. "Modeling and analysis of solar photovoltaic-electrolyzerfuel cell hybrid power system integrated with a floriculture greenhouse," Department of Mechanical Engineering, Bengal Engineering \& Science University, Shibpur, West Bengal, 2010.
[23] K. Ro, and S. Rahman, "Battery or Fuel Cell Support for an Autonomous Photovoltaic Power System," Renewable energy, vol. 13, no. 2, pp. 203-213.

[24] J. Guan, N. Minh, B. Ramamurthi, J. Ruud, J.-K. Hong and P. Riley. "High Performance Flexible Reversible Solid Oxide Fuel Cell," United States Department of Energy , Torrance, 2004.

[25] W. Saeed, and G. Warkozek, "Modeling and analysis of renewable PEM fuel cell system," International Conference on Technologies and Materials for Renewable Energy, Environment and sustainability, pp. 87-101, 2015.

[26] G. Wu, K. Y.Lee, L. Sun, and Y. Xue. "Coordinated fuzzy logic control strategy for hybrid PV array with fuel-cell and ultra-capacitor in a Microgrid," Department of Electrical and Computer Engineering, Bejing, 2017.

[27] M. Hosseini, I. Dincer, and M. Rosen. "Investigation of renewable energy-Based integrated system for baseload power generation", Progress in Sustainable Energy Technologies:, Generating Renewable Energy, pp. 21-46, 2014.

[28] M. M. Elamari. "Optimisation of Photovoltaic Powered Electrolysis for Hydrogen Production for a Remote Area in Libya," PhD, University of Manchester, Manchester, 2011.

[29] Business Juice. "Business energy prices by region," 2017. [Online]. Available: https://www.businessjuice.co.uk/energyguides/energy-prices-by-region/. [Accessed 24 July 2018].

[30] N. Hill, and R. Watson. "2016 government GHG conversion," Department of Business Energy \& Industrial Strategy (BEIS), London, 2016.

[31] D. Steward, M. Penev, G. S. Becker, and W. Becker. "Modeling electricity, heat, and hydrogen generation from fuel cell-based distributed energy systems," National Renewable Energy Laboratory, 2013. 
[32] Clean Energy Council. "Clean energy Australia," 9 April 2018. [Online]. Available: https://assets.cleanenergycouncil.org.au/docum ents/resources/reports/clean-energyaustralia/clean-energy-australia-report-2018.pdf. [Accessed 1st March 2019].

[33] J. Lagorse, D. Paire, and A. Miraoui. "Sizing optimization of a stand-alone street lighting system powered by a hybrid system using fuel cell, PV and battery," Renewable Energy, vol. 34 , no. 3, pp. 683-691, 2009.

[34] M. Jamshidi, and A. Askarzadeh. "Technoeconomic analysis and size optimization of an off-grid hybrid photovoltaic, fuel cell and diesel generator system," Sustainable Cities and Society, vol. 4, pp. 310-320, 201.

[35] M. Qandil, R. Amano, and A. Abbas, "A standalone hybrid photovoltaic, Fuel Cell and Battery System," Proc. of the ASME 2018 12th International Conference on Energy Sustainability, pp. 24-28, 2018.

[36] H. Rezkab, E. Taha, M. Al-Dhaifallahe, M.Obaidcf, A. Hashema, M.El-Sayedb, M. Ali, and G.Olabi. "Fuel cell as an effective energy storage in reverse osmosis desalination plant powered by photovoltaic system," Energy, vol. 175, pp. 423-433, 2019. 